\title{
ECOLOGY OF THE GYRFALCON IN FINNMARK BASED ON DATA FROM TWO 11-YEAR PERIODS 150 YEARS APART
}

\author{
Kenneth Johansen ${ }^{1 *}$ and ArVe $\emptyset_{\text {StLyngen }}^{2}$ \\ ${ }^{1}$ Kautokeinoveien 25, 9518 Alta, Norway. E-mail: kennethalta@hotmail.com \\ ${ }^{2}$ Stillaveien 26, 9517 Alta, Norway. E-mail: aoestly@online.no \\ *Corresponding author
}

\begin{abstract}
Various studies have suggested regional declines in Gyrfalcon (Falco rusticolus) populations. The most dramatic decline was described by Tømmeraas (1994) in a restricted area of Swedish, Finnish, and Norwegian Lapland, where 31 Gyrfalcon nesting localities had been reported by John Wolley and local egg collectors in the mid-19 $9^{\text {th }}$ Century. In 1993, these 31 localities were re-examined, and only four were occupied by stable pairs. From this finding, Tømmeraas estimated a decline in the Gyrfalcon population of $87 \%$ during the 140 years that had passed. Authors have later referred to this figure and its implication of an almost complete loss of the 1860s-population.
\end{abstract}

Our study is the first to compare data from exactly the same area in which the egg collecting took place. For each period, the data sampling covered more than a decade, bracketing a total time-span of as much as 157 years. Of the Gyrfalcon nesting localities described from Lapland in the mid$19^{\text {th }}$ Century, 23 of the 31 were located in Finnmark, northern Norway. The distribution of these 23 Gyrfalcon nest sites defined our study area of $1,800 \mathrm{~km}^{2}$. The historical data from the 11-year period 1854-1864 revealed a total of 46 collected clutches. Monitoring the same area in the 11year period 2000-2010 confirmed 44 Gyrfalcon nesting attempts, almost identical to the earlier period. In the study area, the maximum number of Gyrfalcon clutches collected in a single year between 1854 and 1864 was seven. In our study, starting 146 years later, the maximum number of nesting attempts per year was eight. In the period from 2000-2010, the peak in number of breeding Gyrfalcons corresponded to the peak in Willow Ptarmigan (Lagopus lagopus) abundance.

Thus, our study suggests that the overall number of Gyrfalcon nesting attempts has not changed during the last two centuries. More than $60 \%$ of the known historical nesting territories are still in use. In many of the abandoned nesting territories, there was evidence of human disturbance or environmental changes, e.g. expansion of birch (Betula pubescens) forests. The increased abundance and breeding of Golden Eagles (Aquila chrysaetos) in the region may also have an adverse effect on the breeding Gyrfalcons. Received 6 March 2011, accepted 26 June 2011.

Johansen, K., And A. ØstLYngen. 2011. Ecology of the Gyrfalcon in Finnmark based on data from two 11-year periods 150 years apart. Pages 141-160 in R. T. Watson, T. J. Cade, M. Fuller, G. Hunt, and E. Potapov (Eds.). Gyrfalcons and Ptarmigan in a Changing World, Volume II. The Peregrine Fund, Boise, Idaho, USA. http://dx.doi.org/10.4080/gpcw.2011.0215 
Key words: Gyrfalcon, population trends, nest site fidelity, vegetation changes, fluctuations, egg collecting.

LANDSCAPE CHARACTERISTICS in much of the breeding range of the Gyrfalcon (Falco rusticolus) are changing due to increased human activity and global climate influence. Such alterations in breeding habitat are usually considered to be negative for Gyrfalcon populations (e.g., Burnham et al. 2005, Koskimies 1999, Tømmeraas 1993). In Iceland, however, man-caused deforestation is considered a positive change with respect to Gyrfalcons (Nielsen in Cade et al. 1998, p 5). Understanding long-term population dynamics of the Gyrfalcon is essential if one is to differentiate declines from natural fluctuations (e.g., Koskimies 1999).

The global Gyrfalcon population is dispersed over vast and remote areas in the circumpolar zone (e.g., Booms et al. 2008, Potapov and Sale 2005). The geography of the Gyrfalcons' breeding areas, combined with the early breeding cycle of the species (Booms et al. 2008), makes population studies challenging. However, monitoring programs in Norway, Sweden, and Finland have produced reliable data on the size of the Fennoscandian breeding population during the last two decades (e.g., Østlyngen et al. 2011, Furuseth and Furuseth 2009, Opheim 2008, Ekenstedt 2006a, Koskimies 2006, Falkdalen et al. 2005, Johnsen 2004). Population trends are discussed by several authors. The worldwide population is considered stable (Potapov and Sale 2005, Cade et al. 1998). In North American studies, no long-term population changes are reported (Booms et al. 2008, Mossop and Hayes 1994, Shank and Poole 1994, Swem et al. 1994). In contrast, several Norwegian authors report negative long-term population trends from different areas (Furuseth and Furuseth 2009, Frydenlund-Steen and Sørli 2005, Tømmeraas 1993). The most alarming result was found by Tømmeraas (1994). He compared egg collecting data from northern Norway in the $19^{\text {th }}$ Cen- tury with the presence of Gyrfalcons at the same localities in a single year, 1993, and inferred from this that a profound crash had occurred in the Gyrfalcon population: Only 4 of 31 historical eyries held falcons in that particular year, and from this he stated a population reduction of $87 \%$. A similar survey had been conducted in 1991, and Tømmeraas' (1993) preliminary estimate of the population crash was then $81 \%$. In 1998, Tømmeraas (1998) reported the decrease as $78 \%$, and this number was repeated in 2004 (Tømmeraas 2004). The study design used by Tømmeraas $(1993,1994)$ has been questioned by other authors (Koskimies 2006, Cade et al. 1998).

It is established that the Gyrfalcon productivity show multifold variation in long-term cycles (Koskimies 2006, Mossop and Hayes 1994). Studies designed to evaluate long-term population changes should cover time spans long enough to minimize the effects of these natural fluctuations (Koskimies 2006, Newton 1979).Upon examination, many of the studies suggesting declines in Gyrfalcon populations have covered relatively short time spans.

In Finnmarksvidda, human activity has increased considerably during the 158 years since the first Gyrfalcon clutch was collected by oologist John Wolley and his co-workers. Human residence, presence of roads, use of fossil fuels, hunting pressure on game-birds, Reindeer (Rangifer tarandus) numbers, and eco-tourism have all increased. In addition, the vegetation of the area has become increasingly forested (Tømmervik et al. 2004). In contrast to previous assessments (Tømmeraas 2002), the Golden Eagle (Aquila chrysaetos) now breeds regularly in the area. These changes, as well as the claimed population crash in the Gyrfalcon population, give reason for concern about the status of the species. 


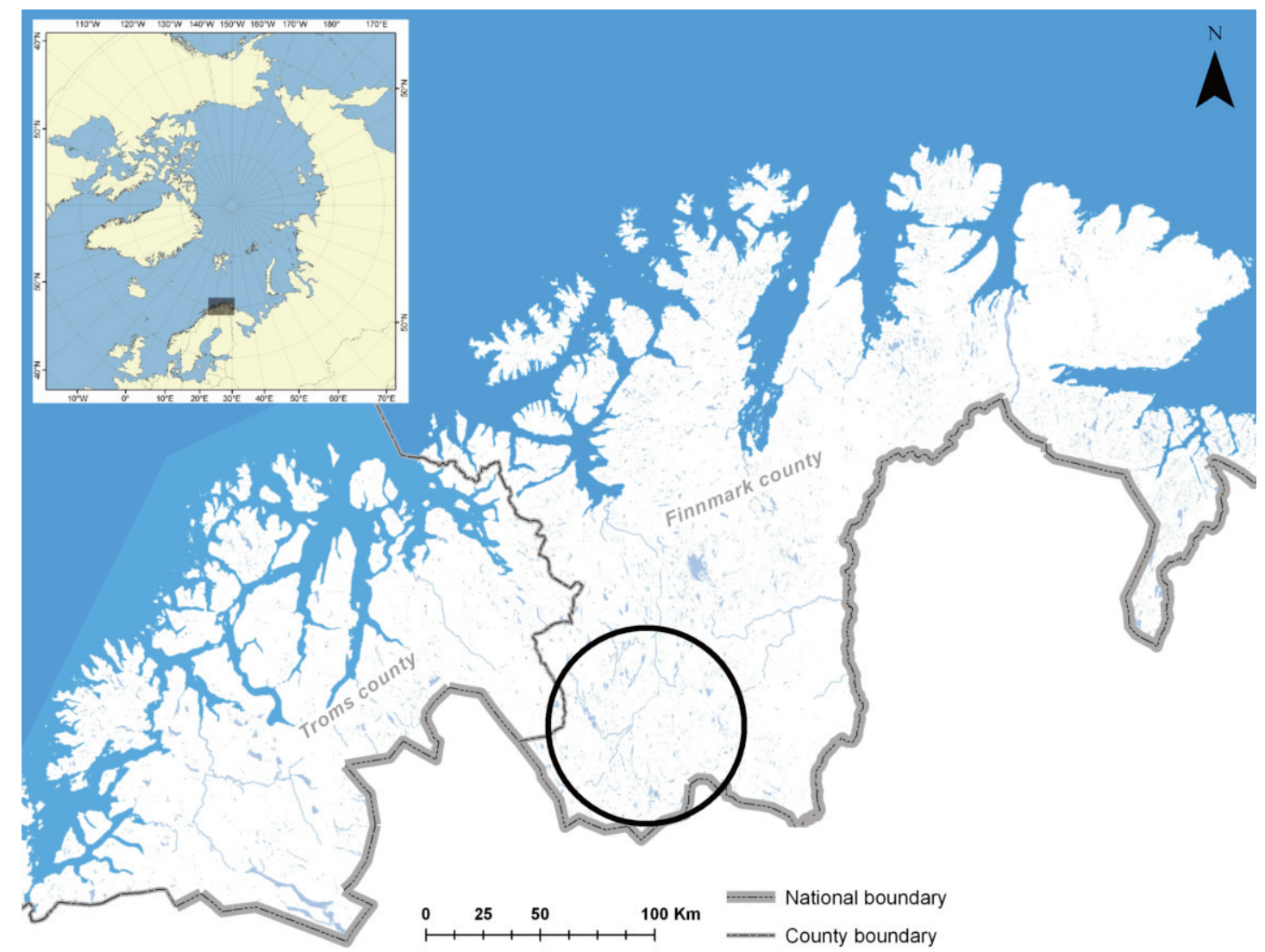

Figure 1. The study area was located within the circle in the map.

We designed our study to minimize the effect of short-term fluctuations in interpreting population trends, by comparing historical data from a period of more than a decade in the mid- $19^{\text {th }}$ Century with a similar period in the $21^{\text {st }}$ Century. Our main approach was to compare the number of collected clutches in the period from 1854-1864 with the number of nests containing incubating birds or young Gyrfalcons observed during 2000-2010.

Gyrfalcons may use the same nest sites for long periods. In Greenland it is known that a nest has been used by Gyrfalcons for more than 2,300 years (Burnham et al. 2009). Our second objective was therefore to document the current status of the historical nesting territories. Gyrfalcons in the area have used old nests of the Common Raven (Corvus corax) or imitations of such (i.e. artificial nests) in $88 \%$ of breeding attempts (Østlyngen et al. 2011). Finally, due to interspecific competition for nesting territories between Golden Eagles and Gyrfalcons (Potapov and Sale 2005, Cade et al. 1998, Watson 1997, Platt 1989), we also monitored nests and breeding activity of Golden Eagles in the study area.

Study Area.-The study area is located at Finnmarksvidda in northern Norway. The area encompasses c. 1,800 $\mathrm{km}^{2}$, situated within the borders of the municipality of Kautokeino (Figure 1).

The total area of the municipality is $9,707 \mathrm{~km}^{2}$, and the human population density 0.3 per $\mathrm{km}^{2}$ (Statistics Norway 2011). Major portions of both the residents and roads in the municipality 


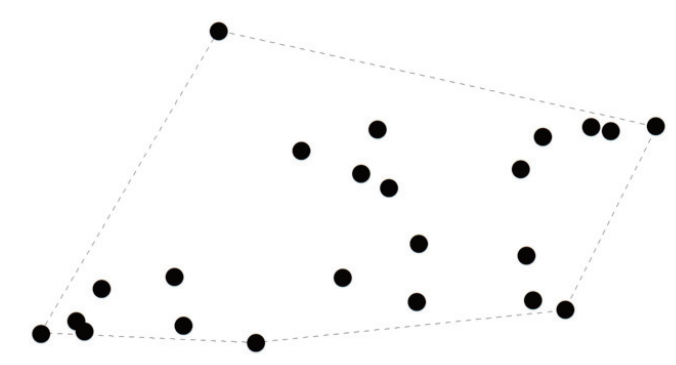

Figure 2. Spatial distribution of the historical Gyrfalcon nest sites, and outline of our study area comprising $1800 \mathrm{~km}^{2}$.

Table 1. Transcript of the index of The Alfred Newton notebook collection at The University Museum of Zoology, Cambridge.

\section{Alfred Newton Listing:}

(1) [1843-1906] John Wolley's notebooks: 12 volumes from which Newton compiled his Ootheca Wolleyana . [there is a 6 and a $6 a=13$ vols.]

(2) 1848 Catalogue of Collection of Bird's eggs. Alfred and Edward Newton. 1 vol.

(3) 2 notebooks belonging to Alfred Newton. 2 vols.

(4) 1857. Ludwig's [Knoblock] Journal [son of F.W.Knoblock] 1 vol.

(4a) 1857-1864. F.W. Knoblocks' Egg Book [Äggböcker] 1 vol. are located within the study area. There is considerable Reindeer husbandry in the area, mainly during winter. The elevation in the study area is c. 270-890 meters above sea level. We defined the study area on the basis of the nest sites described in the mid-1800s. The historical eyries were mapped, and the study area was conservatively defined by straight lines from nest site to nest site on the periphery of the area, representing the external borders (Figure 2).

\section{METHODS}

Analyzing Historical Data.-The British oologist, John Wolley, collected bird eggs in Lapland in the mid- $19^{\text {th }}$ Century, and Gyrfalcon eggs were among the most valued. The results of Wolley's efforts, and some short notes from the collecting of Gyrfalcon eggs, were described in his major work Ootheca Wolleyana (Newton and Wolley 1864). The notes in Ootheca Wolleyana, however, were too brief to locate the nest sites accurately, but provided useful information on the number of clutches collected, clutch size, year of collection, region, and country. The notes from which Ootheca Wolleyana was compiled, as well as supplemental notes from the same time period, were located at The University Museum of Zoology in Cambridge, UK. We visited those collections to study the notebooks. They had no archive numbers in the museum, but were registered under the name of the egg collector and donor, Alfred Newton, and comprised 18 books produced by five different persons (Table 1). In total, c. 4,000 pages of hand written notes were investigated in search of relevant information.

Interpretation of the old notes was not straightforward, as the names of the nest sites were in the Sami language. The egg collectors and buyers probably transcribed the names of the locations based on the Sami pronunciation given by their local co-workers. This resulted in differently spelled names from one year to another, and the spellings did not agree with 
the equivalent names on modern maps. However, knowledge of the area, interpretations of descriptions of terrain, and a philological approach to the names made it possible to identify most of the places mentioned. Where two or more possibilities remained, we visited all alternative places to determine which the likely historical nesting site was.

Field Study.-Prior to the study period, all cliffs with a potential for raptor breeding were checked. Gyrfalcon nests not previously known, as well as Common Raven nests, were mapped. Nests judged suitable for subsequent use by Gyrfalcons were re-visited in later surveys. All known historical sites were visited. During the 2000-2010 field study, all of the identified nest sites were surveyed annually, including both the nest sites described 150 years earlier, as well as those known to us through more recent surveys. We had provided some of the historical territories with an artificial nest in advance, as part of other studies (see Østlyngen et al. 2011). The Gyrfalcon localities were surveyed for nesting in April or during the first days of May. We demanded, at minimum, the observation of an incubating bird to conclude an actual nesting attempt. Observations of nests with young later in the season were also defined as positive nestings. Nests and nesting attempts of Golden Eagles were also recorded.

We accessed nesting territories mainly by snowmobile, but also by some skiing during winter and spring. After the first week of May we accessed most sites on foot, though some surveys were conducted by helicopters or fixed-wing aircraft in late June or early July.

\section{RESULTS}

We mapped the distribution of historically collected Gyrfalcon clutches and current nesting attempts, as well as nesting attempts by Golden Eagles: Table 2 provides an overview. Site numbers given in parentheses elsewhere in this paper refer to those given in Table 2.
Gyrfalcon Clutches Collected from 18541864. - In the data from the period 1854-1864, we found evidence of 46 clutches collected from a total of 23 nest sites in Norway. This does not include an apparent second clutch produced at site 17 in 1863 after the first had been collected. A clutch was collected at this site between 19-25 April 1863. The name of the cliff was specified (site 17), and the collector was Rasmus Persen Spein. One month later, on 14 May, Anders Persen Spein collected another clutch from a nest located on a cliff with an identical name, although given in a different language. The first name was reported in the Sami language [K.wara], the next in the Finnish language [K.tonturi]. The men who collected the two clutches, Anders and Rasmus, were brothers (Steen and Aarseth 1988). We consider it likely that the brothers collected and sold eggs from the same nest; thus a replacement clutch is likely. The second clutch described here is therefore in addition to the 46 historical clutches discussed in this study. It is known that Gyrfalcons may lay a replacement clutch following loss of the initial clutch (Swem et al. 1994, Platt 1989, 1976, Poole 1988, Cade 1960). One collected clutch was accompanied by insufficient information to determine the exact nesting territory, hence the location remains unspecified (site 31). However, it might well be one of the 23 identified sites, because it was collected in the same area where three of the historical nest sites (sites 18, 19, and 21) were located. Breeding was not documented at any of those sites in 1863. The maximum number of egg clutches harvested in one year was seven. In 1860, no clutches were reported (Figure 3).

Gyrfalcon Nesting Attempts from 20002010.- In the period 2000-2010, we confirmed 44 nesting attempts of Gyrfalcons in the study area, and breeding was documented every year. We recorded some of the nesting attempts in artificial nests. The maximum number of breeding Gyrfalcon pairs in a single year was eight, although non-breeding birds were observed in other territories. In 2006, eight 
Table 2. Overview of historical clutches collected and recent nesting attempts are shown in black, and Golden Eagle nesting attempts are in grey. A single case of both Golden Eagle and Gyrfalcon nesting attempt in the same territory is shown in dark grey.

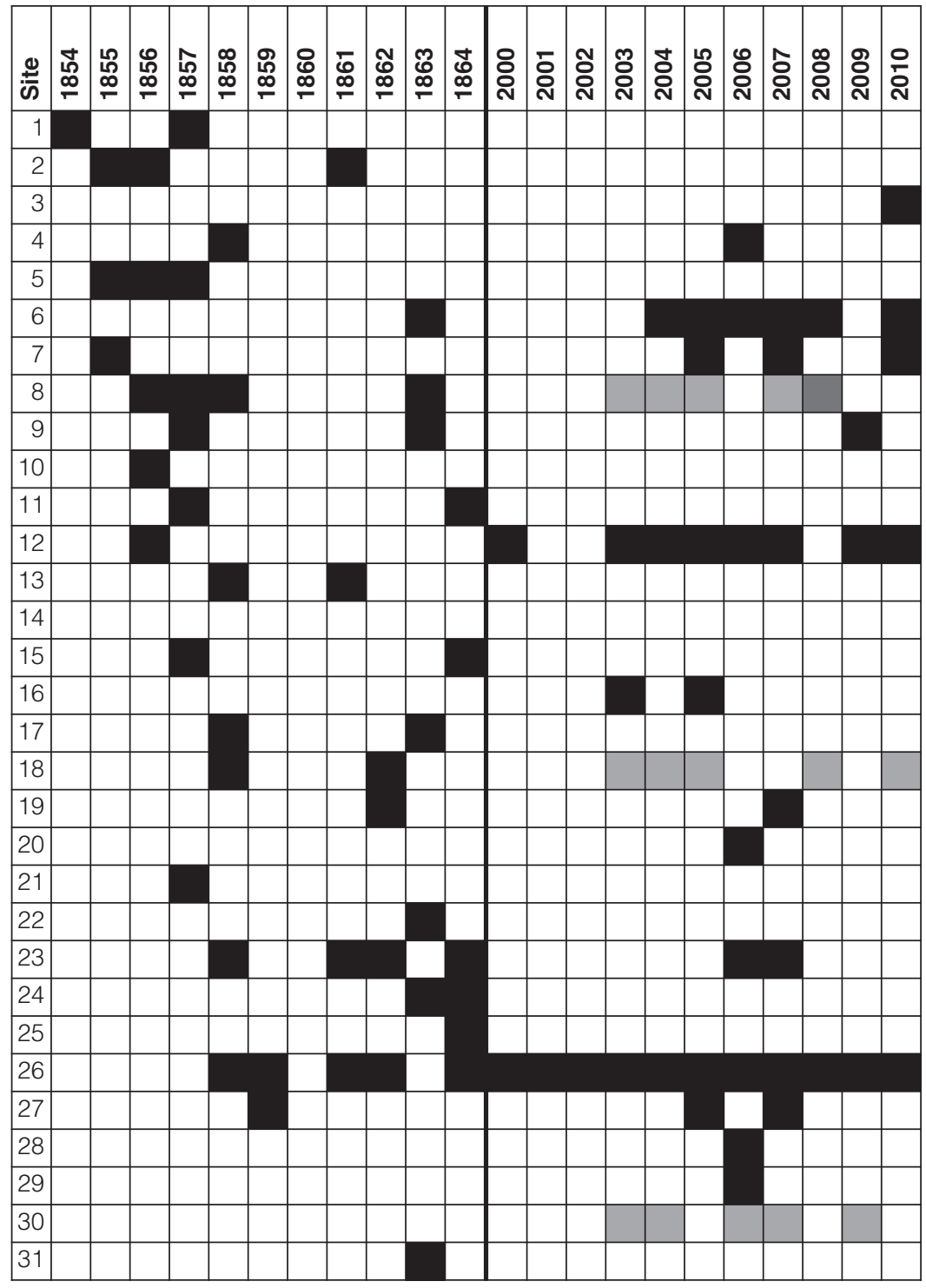

incubating birds were observed, and non-breeding Gyrfalcons were recorded at another five territories. Thus, a minimum of 13 territories was occupied in 2006. In 2001 and 2002, only one nesting was confirmed each year (Figure 4). Nesting attempts after 2000 took place in a total of 16 different territories, of which six were not described in the old notebooks.

Status of the Nesting Territories from the $19^{\text {th }}$ Century.-Our analysis of the historical data revealed 23 names representing different Nor- wegian nest sites (not nesting territories: see Appendix). An additional clutch was collected from an unnamed location. Among the 16 sites where we confirmed nesting attempts after 2000,10 were at the 23 nest sites described by the egg collectors c. 150 years earlier (Table 2 and Figure 5). At the remaining 13 historical nest sites, we could not verify nesting by Gyrfalcons during 2000-2010. At the abandoned sites we found evidence of human disturbance, expansion of birch forest, lack of suitable nests, or competition with Golden Eagles (see 


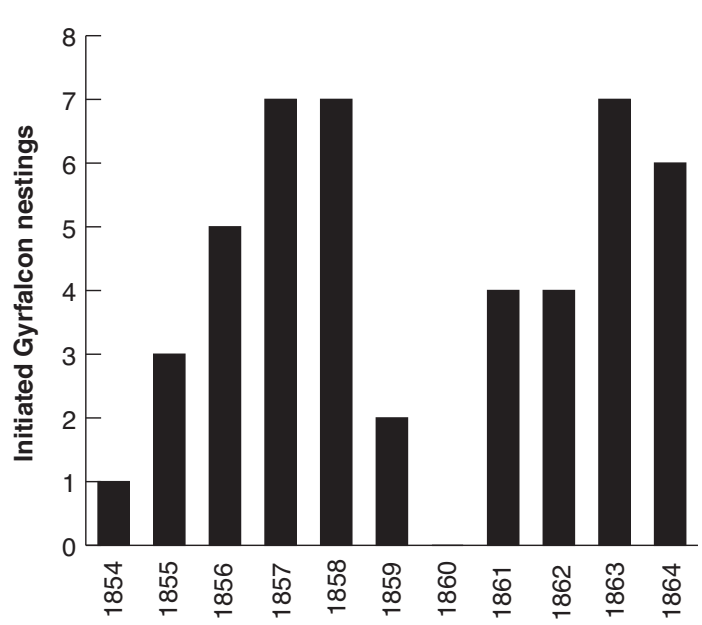

Figure 3. Number of Gyrfalcon clutches collected per year from 1854-1864.

Appendix). The six active nest sites from the 2000 s that were not historical sites were located $1.1-8.6 \mathrm{~km}$ (mean $4.2 \mathrm{~km}$, middle 3.8 $\mathrm{km}$ ) from the nearest historical nest site (Figure 5).

Golden Eagle Observations.-We found 15 nesting attempts by Golden Eagles in the study area during the study period 2000-2010. The attempts occurred at three different sites (sites 8, 18 and 30), with five nest attempts at each site. Two had been described as Gyrfalcon nest sites in the data from the $19^{\text {th }}$ Century (Figure 5). Gyrfalcons nested in both sites in the 1990s, but disappeared when eagles colonized the cliffs at sites 8 and 18. However, Gyrfalcons were found nesting again some years later, only a few kilometers from their historical cliffs and the breeding eagles (Table 2, sites 8, 19 and 20, and Figure 5). In the third eagle nesting territory (site 30), we recorded no interactions with Gyrfalcons. We also found Golden Eagle stick nests at another four localities, but with no confirmed nest attempts in the study period. One of these was discovered in June 2010: two stick-nests separated by some few meters, with feces and prey remnants indicating nesting attempts by Golden Eagles and Gyrfalcons, respectively. The nests

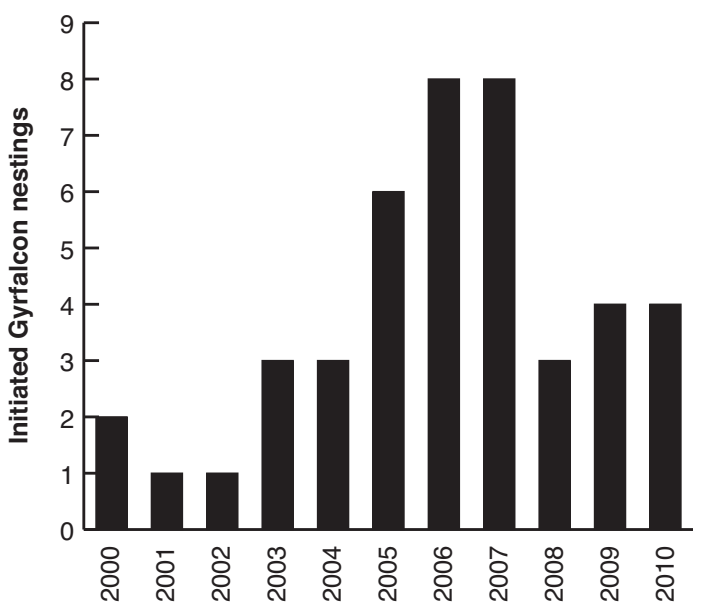

Figure 4. Number of Gyrfalcon nesting attempts per year from 2000-2010.

were on a cliff not previously known to us nor mentioned in the historical literature. We consider it likely that nesting by both species occurred at this cliff after 2000 . However, we can not confirm this, and the findings are not included in the figures or in the following discussion.

\section{DISCUSSION}

Estimates of Gyrfalcon population size should preferably be done by obtaining data over long periods of time due to the natural fluctuations of populations (e.g., Koskimies 2006, Cade et al. 1998). It is well established that European Gyrfalcon populations fluctuate with the densities of ptarmigan (Lagopus spp), the main prey (e.g., Nyström et al. 2005, Nielsen 1999, Nielsen and Pétursson 1995, Hagen 1952). The Lapps were already aware of this dependency 150 years ago. In one of the old notebooks, 1859 is described as a "bad year" for the falcons. Eggbuyer F. Knoblock reported from his conversation with a Lapp selling eggs in 1859 (translated from Swedish) (Figure 6) that “... they [the egg-collecting Lapps] have been checking all nests around Kautokejno and Autzi, but they were all empty. They think that the reason for this is that there are no ptarmi- 
Figure 5. Map showing historical Gyrfalcon territories still used for nesting, as well as abandoned eyries, Golden Eagle nest sites, and nest sites of Gyrfalcons identified in modern times.

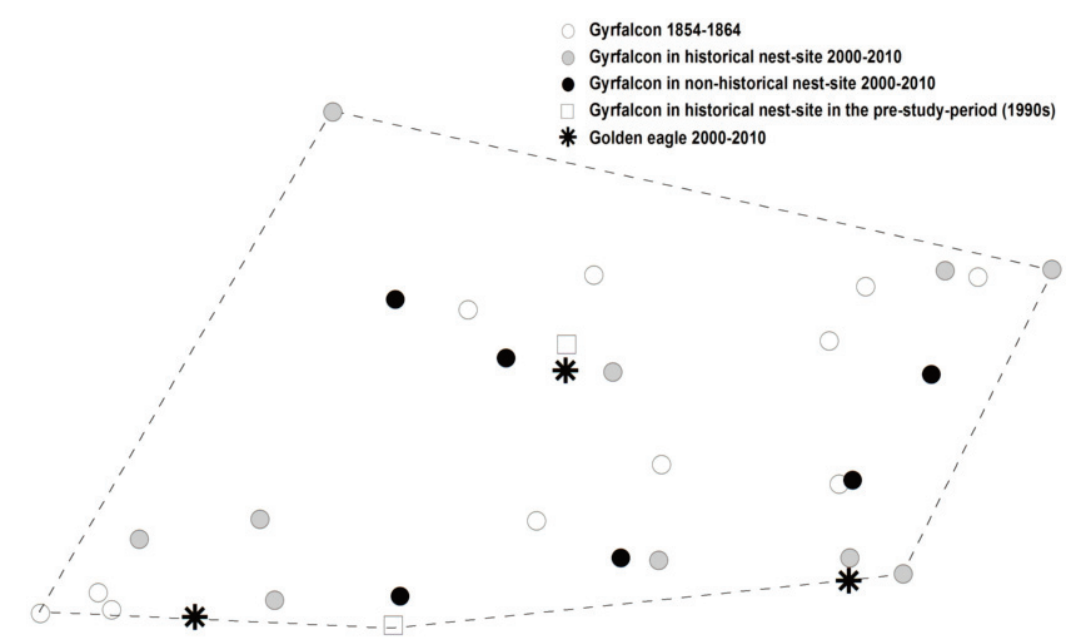

Figure 6. The original manuscript where the Lapp proposed the Gyrfalcon dependency on ptarmigan in 1859.

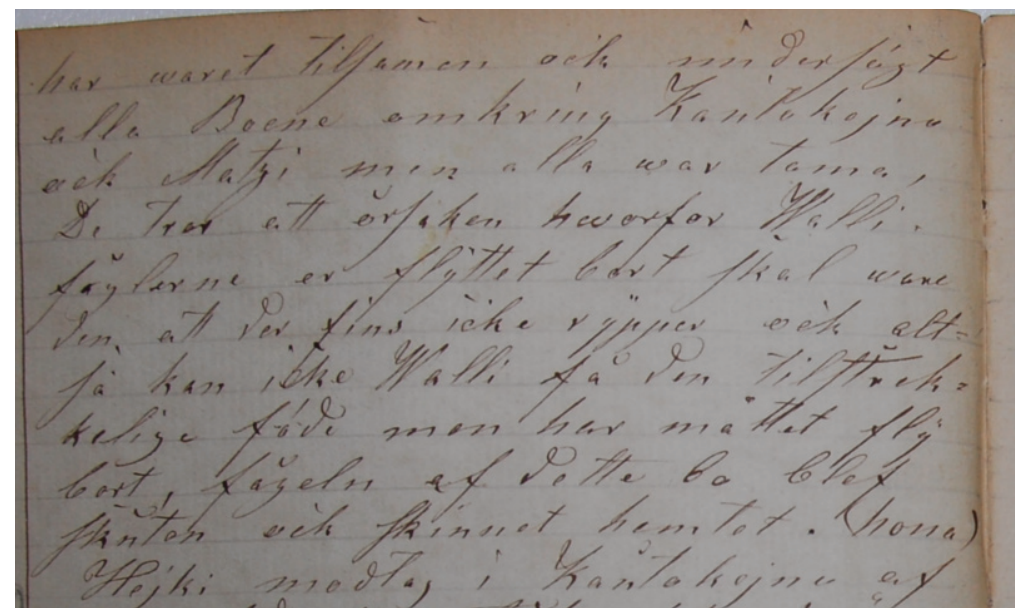

Figure 7. Arve Østlyngen visiting a typical Gyrfalcon nest on a small cliff, partly obstructed by trees. This site was also used by nesting Gyrfalcons in the 1800s.

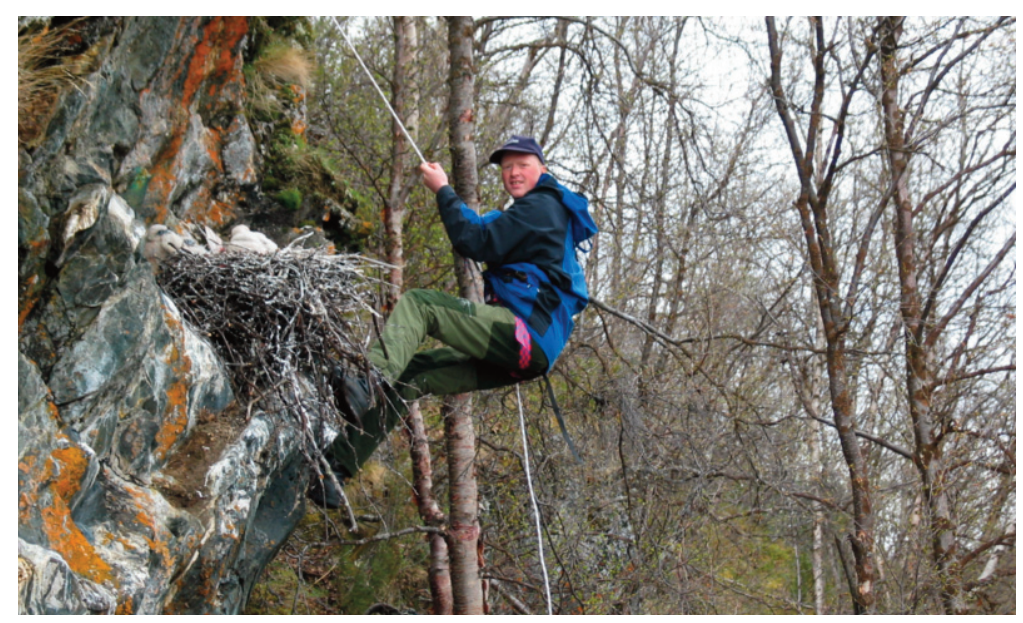


gans abundant. The falcons have left the area due to lack of ptarmigans. The falcons can not get sustainable amounts of food, thus have escaped the area." The following year (1860), no Gyrfalcon clutches were reported from the study area (Figure 3).

The present study suggests that the Gyrfalcon breeding population, in terms of attempted nesting, is at the same level today as it was in the mid- $19^{\text {th }}$ Century. The Gyrfalcon, to a large extent, still uses the same nest sites and territories as 150 years ago: more than $60 \%$ of the nesting territories from the 1800 s have been used during the last two decades. In abandoned territories, we observed evidence of human activity, increased forestation, shortage of stick-nests and abundance of Golden Eagles, all factors that may have adverse effects on the re-use of historical eyries by Gyrfalcons. Our study supports Koskimies' (2006) assumptions of a larger and more stable Gyrfalcon population in Fennoscandia than estimated only a few decades ago. The findings also support other modern interpretations, suggesting a stable Gyrfalcon breeding population worldwide (Booms et al. 2008, Potapov and Sale 2005, Cade et al. 1999).

Generally, raptor populations are limited by the availability of food and nest sites (Newton 1979). Global warming and increased forestation (Tømmervik et al. 2004) may affect ptarmigan numbers, hunting areas, and cliffs suitable for Gyrfalcon nesting, the latter because many of the cliffs in the area are so small that increased size and number of trees in front of them will obstruct them to varying degrees (Figure 7).

It has been proposed that the lack of suitable stick-nests is a limiting factor for Gyrfalcon reproduction (Koskimies 2006, Shank and Poole 1994, Tømmeraas 1993). In our study area, stick-nests of Common Ravens or artificial nests comprised $88 \%$ of the Gyrfalcons nests (Østlyngen et al. 2011). Lack of nests by the Common Raven is suspected to be the rea- son for the abandonment of at least two of the historical nest sites (Table 2, sites 11 and 17). The Lapps were already aware 150 years ago that Gyrfalcons and Ravens used the same nests. Several descriptions of Ravens nesting in old nests used by Gyrfalcons were mentioned, but, as far as we know, no examples of the converse (Gyrfalcons nesting in Ravens nests) were recorded. Hence, we could not confirm that the egg collectors knew which of the two species actually built the nests. Another finding in the notes from the $19^{\text {th }}$ Century is also linked to the Gyrfalcon's dependency on the Common Raven, though it remains unknown if the Lapps or the Englishmen observed the connection 150 years ago: In two locations $4.9 \mathrm{~km}$ apart (sites 1 and 2), Gyrfalcons bred in alternate years while Ravens bred in the same two sites when the Gyrfalcons had moved to the alternate site. Hence, this was probably a single territory, with two alternative nest sites.

Breeding Numbers.- The numbers of nesting attempts during the two 11-year periods compared in this study were 46 and 44 , respectively. The maximum number of nesting attempts per year was seven in the 1900 s, and eight in the 2000s. The minimum number recorded was zero and one, respectively. The numbers therefore indicate no significant difference in the numbers of nesting attempts by Gyrfalcons in the area between 1860 and 2010.

Kautokeino is one of the most popular areas for game hunting in Norway. The level of hunting pressure is indicated by the fact that 1,084 hunting licenses for the municipality were purchased in 2007, a year with game fairly abundant (NRK Sápmi 2008). The main game-bird is the Willow Ptarmigan (Lagopus lagopus). Statistics on hunting outcome are based on semi-scientific data sampling, but they provide an indication of the autumn abundance of ptarmigan in the area. The number of Gyrfalcon nesting attempts in the study area after 2000, and the number of Willow Ptarmigan reported shot in Finnmark County (Statis- 


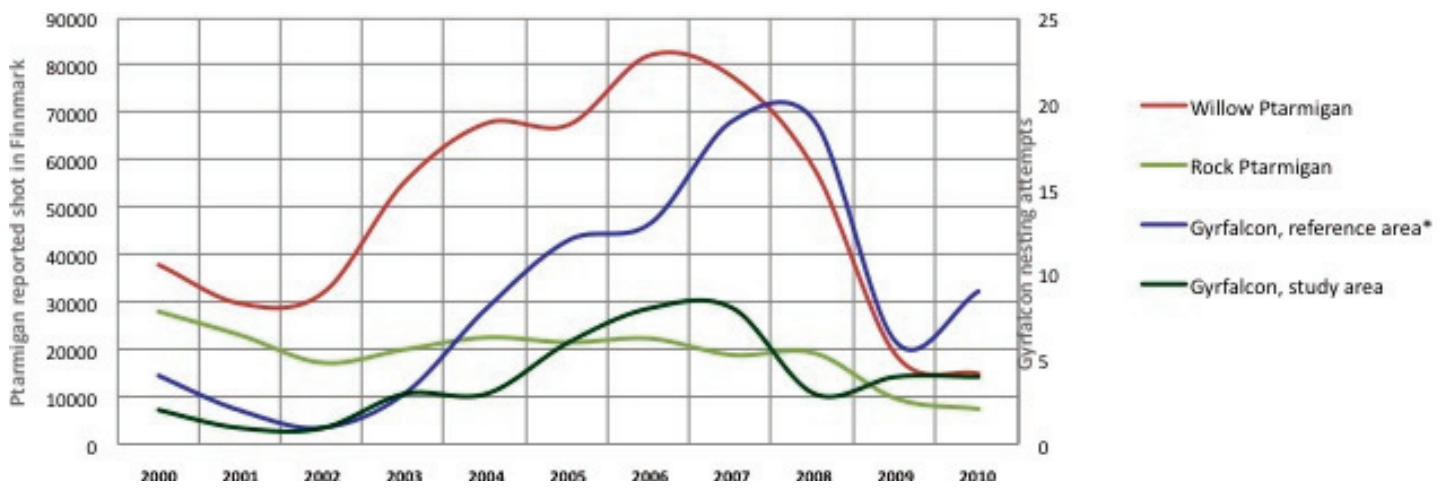

Figure 8. Number of ptarmigan reported shot in Finnmark, and number of Gyrfalcon nesting attempts 2000-2010. *Reference area of 10,000 km², including this study area. Reference area and numbers adapted from Østlyngen et. al 2011.

tics Norway 2010a) are shown in Figure 8. Gyrfalcon nesting attempts in a larger monitoring area of $10,000 \mathrm{~km}^{2}$ (Østlyngen et al. 2011), including our study area, are also shown in the figure for reference. The figure suggests that Gyrfalcon breeding is largely dependent on the abundance of Willow Ptarmigan breeding in this part of the range. The Rock Ptarmigan (Lagopus muta) does not show the same fluctuations, and does not seem to have significant effect on fluctuation in Gyrfalcon numbers in this region. Potapov and Sale (2005) consider Hagen (1952) to be the first ornithologist to recognize the relationship between numbers of Willow Ptarmigan and Gyrfalcons. The Lapps' statement on the issue (Figure 6), however, was almost a century prior to Hagen's studies.

Fluctuations in numbers of confirmed nesting attempts in the two time periods show similar patterns (Figs. 2 and 3). As the lowest number of nesting attempts in the recent period corresponds to a collapse in the Willow Ptarmigan population, the lowest numbers in the $19^{\text {th }}$ Century also follow the reported lack of ptarmigan in the same area.

Status of the Nesting Territories Described in the $19^{\text {th }}$ Century.-An evaluation of the status of the eyries described by the egg collectors 150 years ago is important because the Gyrfalcon is known to use the same nesting territo- ries for a very long time (e.g., Burnham et al. 2009, Nielsen and Cade 1990, White and Cade 1971, Dement'ev and Gladkov 1951). Ten of the 23 historical eyries were found to hold nesting Gyrfalcons at least once during the 2000-2010 study period (Table 2). We have evaluated the 13 nesting territories where nesting was not confirmed in the period after 2000 in search of probable reasons for being abandoned (see Appendix). We concluded that the historical figure of 23 nest sites represents a maximum of 21 nesting territories.

Occupancy Rates. - The field studies after 2000 revealed an occupancy rate higher than that recorded in the 1800 s. In the current century, eight of 16 active territories held breeding falcons in the same season, giving an occupancy rate of $50 \%$. The historical recordings revealed a maximum of seven annual nesting attempts among the 21 nesting territories identified, implying an occupancy rate of $33 \%$. Comparing these rates, however, is not straightforward. The historical names describe small territories, many of them very short distances apart. The number of eyries, thus, might be lower than 21. Likewise, there was a minimum of 18 territories after 2000 if the terminology from the $19^{\text {th }}$ Century is applied, but keep in mind the possibility that the falcons had more nest sites to alternate between in the historical period with less human activity. 
Despite the lack of any data suggesting it, we cannot exclude the possibility that the lower historical occupancy rate reflects an underestimation of the historical population.

Given the interpretation of number of nest sites in the Appendix, as many as 11 of the 21 historical nesting territories have been in use in the current century. If one includes the prestudy period of the 1990s, as many as 13 of the 21 historical sites have been used for nesting during the last two decades. The nesting territories from the $19^{\text {th }}$ Century thus have a minimum incidence of use in modern times of $62 \%$. This supports the assumption that these nest sites and territories are very important for Gyrfalcon reproduction. Burnham et al. (2009) found nest sites used for more than 1,000 years in Greenland, the oldest more than 2,300 years. Peregrines are also known for using the same nest sites for hundreds of years (Ratcliffe 1993), and from Wyoming, USA, it has been reported that Peregrines nested on the same ledges that were used 10 years prior to the reoccupation of a cliff (Oakleaf 2003). Newton (1979) regards limited availability of appropriate nesting sites as one of the potential limiting factors of raptor population size. In our study, 24 of the $44(55 \%)$ initiated nesting attempts during the last 11 years occurred in only three of the 16 territories (18\%) (Table 2 sites 6, 12 and 26). These sites were all among those described in the $19^{\text {th }}$ Century. Nielsen (1986) showed a similar pattern from a larger study in Iceland, in which $13 \%$ of the sites accounted for $41 \%$ of the successful nesting attempts. Our finding supports Nielsen and Cade's (1990) postulate that some nesting territories are superior to others in terms of quality of the cliff, with respect to roosting places, nest sites, and access to food, thus producing more offspring than other occupied territories.

The three nest sites mentioned held breeding falcons six, eight, and 11 times, respectively, during the 11 years after 2000 (Table 2). These sites have had a frequency of use of $55-100 \%$. In the historical sample, the most frequently used nest site was robbed five times in the 11year period in the 1800 s, suggesting an occupancy rate of $45 \%$. It is interesting that the most used nest site in the 1800s (site 26) is also the site most used in modern times. A possible explanation of the difference in apparent occupancy rates between the two periods might be that not all the nests were checked every year in the 1800s. A confounding factor is that the names of the modern sites are given and understood with respect to nesting territories, whereas more than one of the historical names might represent alternate nests within the same territory (see Appendix). As we cannot confirm such interpretations, we have to consider the breeding numbers from the 1800 s a minimum estimate.

Gyrfalcon Nesting Density.-The highest numbers of initiated Gyrfalcon nesting attempts in the two periods of our study were seven and eight, respectively, resulting in one active pair of Gyrfalcons per $257 \mathrm{~km}^{2}$ in the $19^{\text {th }}$ Century and one per $225 \mathrm{~km}^{2}$ in modern times. In 2006, eight nesting attempts were recorded, and Gyrfalcons or fresh signs of Gyrfalcons (e.g., droppings, pluckings, prey remnants) were observed at another five locations where nesting was not confirmed. Thus, a minimum of 13 cliffs were held by Gyrfalcons in the study area of $1,800 \mathrm{~km}^{2}$, resulting in an area of $138 \mathrm{~km}^{2}$ per occupied cliff. From the historical data covering the same area, Tømmeraas (1993) inferred a nesting density of one pair per $54-84 \mathrm{~km}^{2}$, but his methodology was not described.

In comparing the present Fennoscandian population to the historical population, observations by Sjölander from the first decade of the $20^{\text {th }}$ Century are often cited (e.g., Potapov and Sale 2005, Koskimies 2006, Cade et al. 1998, Tømmeraas 1993, Hagen 1952). Sjölander published some memoirs almost 40 years after his journeys to Swedish Lapland (Sjölander 1946), but the information is anecdotal and has led to different interpretations by different authors. Some authors refer to 8-11 breeding 
pairs in 1910 (Hagen 1952, Tømmeraas 1993, 1994, 1998, 2004). Sjölander, however, reported the number of breeding pairs found in two consecutive years, 1909 and 1910 . He found eight pairs and was later told that a Lapp knew of another three pairs in the same area. Furthermore, he does not give an exact outline of his "study area", but only mentions that he made his observations between the lake Lule vatten and the watercourse Kaitumälven. Hence, to determine density, subsequent authors have attempted to interpret the size of the area of Sjölander's observations from these general remarks. Hagen (1952) used an area of $1,000 \mathrm{~km}^{2}$ in his discussion, Tømmeraas (1993) interpreted the area as representing 200 $\mathrm{km}^{2}$, whereas Potapov and Sale (2005) found it likely that the area Sjölander visited was $10,000 \mathrm{~km}^{2}$. Tømmeraas' interpretation gave a density of one pair per $18-25 \mathrm{~km}^{2}$ (1993). Given the interpretation that a total of c. ten breeding pairs were found in an area of 1,000 $\mathrm{km}^{2}$ in the 2 years combined, the calculated density would be five pairs per $1,000 \mathrm{~km}$, or $200 \mathrm{~km}^{2}$ per pair. In a long-term study in Yukon Territory, Canada, involving 172 Gyrfalcon nesting territories followed through 18 years, Mossop and Hayes (1994) found nesting density up to $164 \mathrm{~km}^{2}$ per pair. Both the alternative interpretation of Sjölanders paper, as well as the calculated density by Mossop and Hayes correspond to the observed density in the best years of our study, i.e. the years that Willow Ptarmigan were most abundant. We suggest that estimated densities, based on old literature, should be interpreted with caution.

The fidelity of Gyrfalcons to traditional nesting sites and the finding that some sites represent particularly good breeding habitat makes conservation and protection of these specific areas and their surroundings important.

Interspecific Competition with the Golden Eagle.-It has been claimed that the Golden Eagle is not, or has not been breeding in the study area (Tømmeraas 2002, i.e. until 2002). However, from 2003 onward we found the species nesting in the study area several times in three different nesting territories. We also found nests, without signs of breeding, representing another four Golden Eagle eyries.

Two of the active eagle eyries were described as Gyrfalcon nesting sites in the mid- $19^{\text {th }}$ Century, and were used by Gyrfalcons as recently as the 1990s (sites 8 and 18). In both territories, regular Gyrfalcon nesting was recorded in the pre-study period, followed by a few years of non-breeding. In this intermediate period, Golden Eagles were observed regularly, resulting in eagles nesting in both Gyrfalcon territories from 2003 onward (Table 2). Signs and observations of Gyrfalcons were recorded in both territories in the following years, but no Gyrfalcon nesting attempts took place. In 2006, Gyrfalcons nested in a tree $4.7 \mathrm{~km}$ north of the cliff (site 20) that had been taken over by the eagles (site 8 ), and on a small cliff 4.8 $\mathrm{km}$ south of it (site19) in 2007. In the other eagle territory (site 18), the Gyrfalcons nested again in 2008, $3.3 \mathrm{~km}$ south of the incubating Golden Eagle. Our interpretation of these observations is that the Gyrfalcons were displaced from their eyries by the Golden Eagles, although we did not observe any direct confrontations between the falcons and the eagles.

Previous authors have made different conclusions concerning the relationship between Golden Eagles and Gyrfalcons with respect to interspecific territorialism. Ratcliffe (1993) described a sequence of events from Galloway Hills which has several similarities to our observations, though the species involved there was the Peregrine. When Golden Eagles recolonized the area, Ratcliffe found that the Peregrines were immediately displaced from their eyries. He concluded that the Golden Eagle was dominant over the Peregrine. From Alaska, it is known that Gyrfalcons maintain a distance from occupied eagle cliffs (Weir 1982). Poole and Bromley (1988) found that large falcons can breed in disused Golden Eagle eyries if the eagles are using an alternative cliff several kilometers away. Watson 
(1997) mentioned only the Griffon Vulture (Gyps fulvus) as a species capable of displacing Golden Eagles from cliffs. On the other hand, several other observations suggest that the Gyrfalcon can be dominant over the Golden Eagle in certain situations. In Alaska, Platt (1989) observed a pair of Golden Eagles forced to abandon their nest after the first egg was laid, due to aggression from a male Gyrfalcon defending a nest $450 \mathrm{~m}$ away. In the previous year, Gyrfalcons and Golden Eagles nested successfully $800 \mathrm{~m}$ apart on the same cliff. Platt observed that $60 \%$ of 24 Gyrfalcon attacks on Golden Eagles were conducted by the male Gyrfalcon alone.

It is intriguing that authors of recent monographs on the two species involved conclude differently in their respective reviews on this issue. For example, Watson (1997) regarded the Golden Eagle as dominant over the Gyrfalcon, while Potapov and Sale (2005) arrived at the opposite conclusion. A possible reconciliation of these interpretations might be that Gyrfalcons protect their nest and young vigorously against Golden Eagles, as suggested by both Watson (1997) and Potapov and Sale (2005), but prior to egg-laying, Golden Eagles might be dominant in choosing a nesting site, as Ratcliffe (1993) observed with Peregrines and Golden Eagles in Scotland. Records of Golden Eagles and Gyrfalcons nesting in close proximity (e.g., Platt 1989, Poole and Bromley 1989) underscore the complexity of this issue. Cade's statement (1960), more than 50 years ago, may still have value: "Nesting relations between the Gyrfalcon and the Golden Eagle are unknown."

Environmental and Anthropogenic Changes in the Study Area.-Many extrinsic factors have changed considerably in our Gyrfalcon study area during the past 150 years. A number of these were identified and discussed as potential threats to the Gyrfalcon in Birdlife International/EU's Action Plan for the species (Koskimies 1999). The human population has increased from 738 in 1865 (Helland 1906) to
3,076 in 2011 (Statistics Norway 2011). In 1852 , the number of Reindeer that were fed in winter in the municipality of Kautokeino was estimated at 33,000 (Helland 1906). In 2007, it was close to 94,000 (The Directorate for Reindeer Husbandry 2007). Hundreds of kilometers of Reindeer fences have been built in the study area during the last few decades.

The first 11-year period described in this study was in the pre-petroleum era, and there were no roads, cars, or electricity in Kautokeino (Tromholt 1885). In 2009, the stock of registered vehicles in Kautokeino was 3,825, of which 1,164 were snowmobiles (Statistics Norway 2010b).

The vegetation in the study area has changed significantly in recent decades (see figure 2 in Tømmervik et al. 2004) (Figure 9). Their vegetation study, including our study area, showed that the birch forest in Kautokeino expanded by $90 \%$ between 1961 and 2000. In contrast, lichen-dominated heaths and woodland have decreased by approximately $80 \%$. In addition, heavily grazed heaths with less than $25 \%$ lichen coverage appeared in 1987, and have increased ever since.

These habitat changes might have adverse effects on both the Gyrfalcon (Koskimies 1999) and its main prey in the area, the Willow Ptarmigan. Unpublished data from Nielsen (see Cade et al. 1998) indicate a positive impact of an apparently opposite change in habitats in Iceland. There, human land use has created favorable habitat for Rock Ptarmigan and Gyrfalcons by converting birch forest to heathland.

Climate and vegetation in much of the Gyrfalcon's breeding range are changing. This is a special concern in Sweden, where studies have predicted a reduction of Gyrfalcon habitat by $80 \%$ within the next century (Ekenstedt 2006a). Furthermore, the pressure of anthropogenic land use is a continuous threat as the industries of mining, drilling, and forestry are 

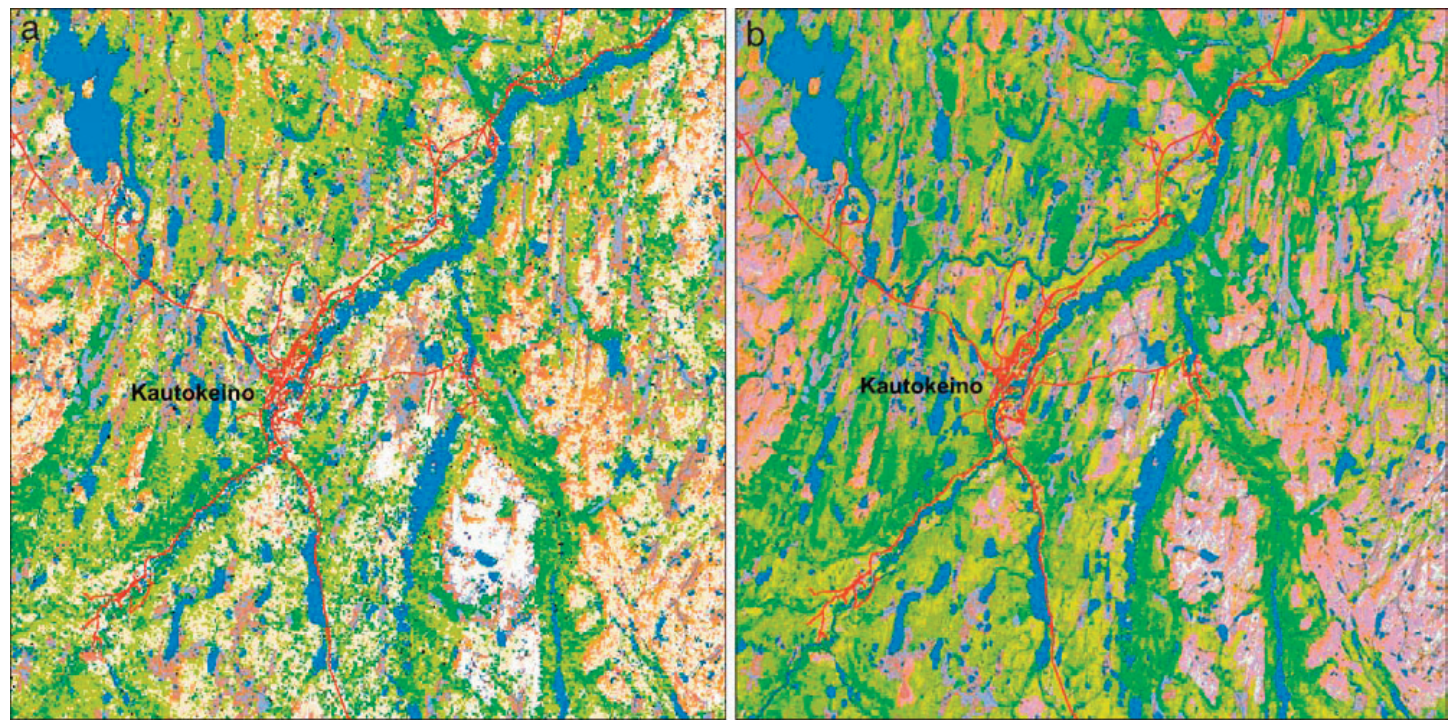

Figure 8. Vegetation cover maps from Kautokeino in (a) 1973 and (b) 2000. Lichen communities are presented in yellow and white, while forests and bilberry communities are presented in green. Violetand brown-colored areas indicate vegetation cover types dominated by dwarf shrub (bilberry) and dwarf birch communities. Duplicated from figure 2 in Tømmervik et al. 2004.

looking to the remote areas of northern Fennoscandia when considering new projects. Deterioration of Gyrfalcon habitat will also have adverse effect on its main prey, the ptarmigan (Koskimies 1999).

Studies Comparing Historical Data to Present Results-and Limitations of Such.-Our study compares historical data with data obtained from recent surveys. A similar approach has been used by other authors (Burnham et al. 2005, Nielsen and Pétursson 1995, Tømmeraas 1993, 1994). From West Greenland, a comparison of data from the early $20^{\text {th }}$ Century with survey data from 2000 indicated a significant decline of the Gyrfalcon population in that area (Burnham et al. 2005). In Iceland, c. 100- and 300-year-old export figures of Rock Ptarmigan and Gyrfalcons, respectively, were analyzed to compare fluctuations in the historical populations to fluctuations confirmed by recent research (Nielsen and Pétursson 1995). In the earlier study in the same region as our study area, Tømmeraas estimated a population decline of $87 \%$ (1994). This study, as well as
Tømmeraas' two studies $(1993,1994)$, all compared egg collecting data from Northern Fennoscandia in the $19^{\text {th }}$ Century with the presence of breeding Gyrfalcons in the same area in modern times. However, Tømmeraas examined strictly the historical nest sites, and only for two single-year periods, whereas we monitored the entire area for 11 consecutive years, a time span equivalent to the period in which the egg collecting took place in the area. Our study design minimized some possible biases applying to Tømmeraas' findings, notably with respect to single-year data as basis for comparison. This methodological issue is discussed more thoroughly by Koskimies (2006).

To our knowledge, the present study is the first to compare data from exactly the same area, the data sampling covering more than a decade in series, and with a time span of as much as 157 years. However, we realize that our study may suffer from limitations. For example, concerns have been raised that the nests found in the $19^{\text {th }}$ Century did not represent all nests (Koskimies 2006). In our opinion, this is not 
very likely, as the nest sites in modern times are still located in the same areas as 150 years earlier (Figure 4). The new nest sites are located an average of $4.2 \mathrm{~km}$ from the nearest historical nest site; hence there seem to be no significant areas with breeding Gyrfalcons about which the Lapps were unaware. In 1859 and 1860 combined, only two clutches were collected, despite the egg collectors knowing of several eyries where eggs were collected in preceding years when numerous nesting attempts occurred, and yet the Lapps specifically mentioned that all nests in the area were checked (Figure 6). Other negative surveys with negative results were also described, including breeding by Ravens in old Gyrfalcon nests. The number of eyries found in the $19^{\text {th }}$ Century was higher than today, another suggestion that intensive surveys were undertaken. According to the historical notes, the Lapps were paid well, and they were experienced in finding and accessing Gyrfalcon nests. Both the motivation and skills should have been sufficient to collect eggs from all available nests. Another aspect revealed from analyzing the old notebooks is that the Lapps moved quite rapidly in the terrain. They used Reindeer to pull a sled with a man inside and were able to move dozens of kilometers in the snow-covered heathlands during a single day; they could thus survey several territories in just a few days.

The borders of our study area were defined by confirmed nesting attempts in the $19^{\text {th }}$ Century; hence, areas with potentially negative historical surveys were omitted. We know of two recently active Gyrfalcon sites less than five kilometers outside the borders of our study area, but these were not included in our results. Both these sites might have been alternates within historic territories. The results of this study are therefore conservative in biasing the results of modern surveys downward.

The historical clutches were given dates and names of locations, hence the possibility that a second clutch was collected from the same nest during the same breeding season is slight, except for the single replacement clutch discussed above.

In comparing recent data to clutches collected 150 years ago, the gold standard would be accessing the nest to verify the existence of eggs by direct observation. To avoid unwanted nest site disturbance and the possibility of interrupting nesting early in the incubation period, we did not use this method (see Poole 1988). On the other hand, there are no indications that the egg collectors in the mid- $19^{\text {th }}$ Century disturbed the birds early in the season, resulting in failure of egg-laying. The Lapps collected the eggs mainly in the last two weeks of April and the first week of May. Modern laying dates in our study area were confined to the two-week prior to c. April 12. (unpubl. notes).

If the egg collectors removed all, or nearly all, clutches every year, a possible concern might be that this constrained the population. The collection of Gyrfalcon eggs, however, was conducted by only a few Lapps and Englishmen in a restricted area. Almost all clutches known collected in Norway were within our study area, and it encompasses less than 2,000 $\mathrm{km}^{2}$. There are viable Gyrfalcon populations in every direction from our study area, and the population is continuous with the Swedish population as verified by genetic studies (Ekenstedt 2006b). Even though there are fewer Gyrfalcon eyries to the immediate south, on the Finnish side of the border, and these were also exploited by egg collectors in the $19^{\text {th }}$ Century, the influx of birds into our study area from viable populations in nearby regions should have been sufficient to compensate for the effects of nest robbing. Replacement clutches were likely more common in the $19^{\text {th }}$ Century than recognized in this study, in which only one single replacement clutch was identified. Replacement clutches would have been difficult to discover due to very restricted possibilities of moving around in the terrain during snow melt, flooding of the rivers, and very wet marshes and woods during the 4-6 weeks 
between the beginning of May and mid-June. However, the activity of egg-collecting continued for other species of birds throughout summer, and we found no descriptions of late Gyrfalcon broods, suggesting that replacement clutches were uncommon.

Our observations at abandoned nest sites are consistent with prevailing concerns that environmental and man-made changes may threaten the Gyrfalcon population. Even in a situation with stable Gyrfalcon numbers, the potential threats must be taken seriously, and monitoring projects should be continued and coordinated. The Gyrfalcon population is relatively small, as compared to most other raptors, making it a vulnerable species. Future research should focus on which efforts and remedial actions are advantageous and realistic in the event the population is negatively influenced by widespread factors such as global warming, as expected.

\section{ACKNOWLEDGMENTS}

This study would not have been possible without the efforts of Olaf Opgård, Trond V. Johnsen, and Bjørnulf Håkenrud, who have been out in the field with us for hundreds of days during the past two decades. Per J. Tøm- meraas introduced us to the Gyrfalcon, as well as to the old oological literature, in the late 1980s. Tom J. Cade's achievements in raptor conservation and his knowledge of Gyrfalcons have been inspiring. Cade also gave his recommendations concerning our access to the historical collections in Cambridge. Cade, Lloyd Kiff, and Peder A. Halvorsen provided valuable comments and suggestions to the manuscript. Vidar Thomassen and Trond V. Johnsen were helpful in preparing illustrations. We are grateful to the staff at the University Museum of Zoology in Cambridge, UK, for their willingness in providing access to the valuable and fragile original manuscripts and notebooks of the pioneer oologists in Lapland from the $19^{\text {th }}$ Century. The Norwegian Association for Nature Research provided access to remote Gyrfalcon nest sites in summer by helicopter, as part of their Golden Eagle studies. The County Governor of Finnmark provided partial financial assistance for our raptor surveys. Frequent discussions with our colleagues on the Finnish side of the border, Pertti Koskimies and Björn Ehrnsten, have been very interesting and motivating through the years. Last, but not least, our absence from home for weeks every year would not have been possible without our supportive families, to whom we are very grateful.

Appendix: Evaluation of historical eyries with no recent nesting attempt by Gyrfalcons:

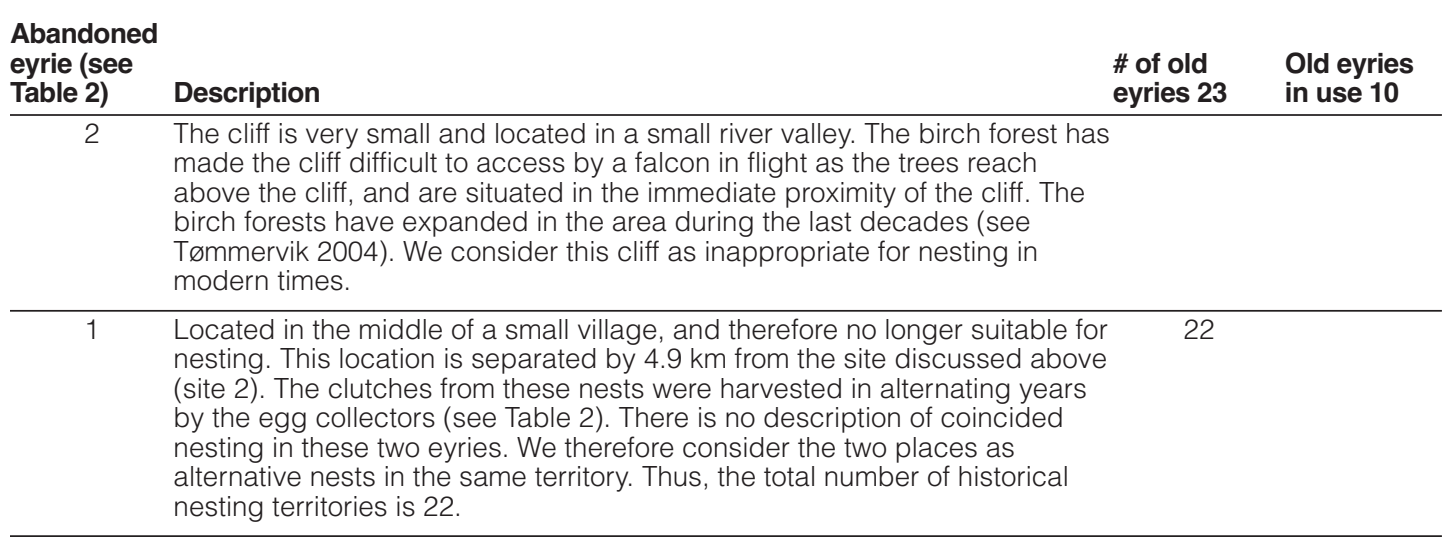




\section{- Gyrfalcon - a 150 year PERSPECtive -}

Appendix (continued): Evaluation of historical eyries with no recent nesting attempt by Gyrfalcons:

\begin{tabular}{|c|c|c|c|}
\hline $\begin{array}{l}\text { Abandoned } \\
\text { eyrie (see } \\
\text { Table 2) }\end{array}$ & Description & $\begin{array}{l}\text { \# of old } \\
\text { eyries } 23\end{array}$ & $\begin{array}{l}\text { Old eyries } \\
\text { in use } 10\end{array}$ \\
\hline 5,4 & $\begin{array}{l}\text { Location } 5 \text { is in a river valley with very small cliffs and dense forest. } \\
\text { Gyrfalcons are observed here, but no nesting has been confirmed after } \\
2000 \text {. However, nesting has taken place on a cliff only } 2.6 \mathrm{~km} \text { away in } 2006 \\
\text { (site 4). This might be an alternative nest in the historical locality (site 5). } \\
\text { Furthermore, this is considered to be the same locality as another of the } \\
\text { historical names (4). The fact that the eyries } 4 \text { and } 5 \text { are separated by only } \\
2.6 \mathrm{~km} \text {, and no coincidental nesting is described in the historical records } \\
\text { implies that these two locations should be considered alternative nests in } \\
\text { the same nesting territory. Accepting this evaluation, the number of } \\
\text { historical nesting territories is reduced to } 21 \text {. }\end{array}$ & 21 & \\
\hline 21 & $\begin{array}{l}\text { The cliff is overhanging a lake used by the locals for fishing during late winter, } \\
\text { coincidental to the pre-laying period and the incubation period of the } \\
\text { Gyrfalcon. However, a Golden Eagle nest was found on the cliff during the } \\
\text { surveys in this century, although eagle breeding is considered not to have } \\
\text { succeeded here. Apart from this, we consider the cliff and its surroundings to } \\
\text { still represent a suitable nesting eyrie. }\end{array}$ & & \\
\hline 11 & $\begin{array}{l}\text { Two clutches were collected (separated by seven years) in this territory that } \\
\text { is apparently still undisturbed, with suitable cliffs, and a viable ptarmigan } \\
\text { population. However, there have been few stick nests available in the area. } \\
\text { We have never observed Gyrfalcons at this location, but Golden Eagles } \\
\text { roost regularly on a summit c. } 2 \mathrm{~km} \text { from the historical eyrie. The summit } \\
\text { also includes a cliff on which Golden Eagles built a nest in the field-study } \\
\text { period. No breeding attempt by the eagles has been observed in this nest. }\end{array}$ & & \\
\hline 15 & $\begin{array}{l}\text { The cliff is located close to a lake frequently visited by anglers in late winter. } \\
\text { This leads snowmobile traffic to the old eyrie, and makes it very unlikely that } \\
\text { the Gyrfalcons will nest there nowadays. An alternative nest with an } \\
\text { incubating bird was located only } 1.1 \mathrm{~km} \text { away in } 2003 \text { (site } 16 \text { ). Considering } \\
\text { this an alternative nest in the same territory increases the number of old } \\
\text { territories occupied in the field study period to } 11 .\end{array}$ & & 11 \\
\hline 17 & $\begin{array}{l}\text { The cliff is located in an apparently suitable area. However, the cliff is very } \\
\text { small, and there have been no available nests here during the field-study } \\
\text { period. }\end{array}$ & & \\
\hline 25 & $\begin{array}{l}\text { The cliff is situated close to what nowadays is a village, and therefore not } \\
\text { suitable for Gyrfalcon nesting. However, there have been Gyrfalcon nesting } \\
\text { attempts during the study period in an eyrie only } 4.8 \mathrm{~km} \text { away. This eyrie is } \\
\text { outside the study area, thus not taken into account in the numbers and } \\
\text { tables in this study. }\end{array}$ & & \\
\hline 18 & $\begin{array}{l}\text { The cliff has not held Gyrfalcon nesting attempts during the study period, } \\
\text { but has been used for nesting by Golden Eagles five times in the same } \\
\text { period (see discussion on interspecific competition). However, Gyrfalcons } \\
\text { nested here several times during the pre-study period in the } 1990 \text { s. } \\
\text { Therefore we do not consider this eyrie to be abandoned by the Gyrfalcons } \\
\text { since the } 19^{\text {th }} \text { century. Accepting this, the number of eyries still in use is } 12 \text {. }\end{array}$ & & 12 \\
\hline 10 & $\begin{array}{l}\text { Also this site, collected in the } 19^{\text {th }} \text { century, is located in what now is a } \\
\text { village, and abandoned. }\end{array}$ & & \\
\hline 24 & $\begin{array}{l}\text { The exact location of this cliff, in which the birds nested } 150 \text { years ago, is } \\
\text { not known. The name covers a watercourse, which is thoroughly examined, } \\
\text { and found to hold no Gyrfalcons in the study period. }\end{array}$ & & \\
\hline 13 & $\begin{array}{l}\text { This location has not held Gyrfalcon nesting attempts in the period } 2000- \\
2010 \text {. However, both the fact that the nesting cliff was in use in the } 1990 \mathrm{~s} \text {, } \\
\text { and that the Gyrfalcons have nested on a cliff (site } 14 \text { ) only } 2.4 \mathrm{~km} \text { away } \\
\text { twice during the field-study period supports the conclusion that this is the } \\
13^{\text {th }} \text { of the old eyries that are still in use. }\end{array}$ & & 13 \\
\hline
\end{tabular}




\section{Literature Cited}

Booms, T. L., T. J. Cade, And N. J. Clum. 2008. Gyrfalcon (Falco rusticolus). In A. Poole (Ed.). The Birds of North America Online. Cornell Laboratory of Ornithology, Ithaca, New York, USA. Retrieved from The Birds of North America Online database: http://bna.birds.cornell.edu.bna/species/114

BURNHAM, K. K, W. A. BURNHAM, AND I. NEWTON. 2009. Gyrfalcon Falco rusticolus post-glacial colonization and extreme longterm use of nest-sites in Greenland. Ibis 151(3):514-522.

Burnham W. A., K. K. Burnham, and T. J. CADE. 2005. Past and present assessments of bird life in Uummannaq District, West Greenland. Dansk Ornithologisk Forenings Tidsskrift, 99:196-208.

CAdE, T. J. 1960. Ecology of the Peregrine and Gyrfalcon populations in Alaska. University of California Publications in Zoology. 63:151-290.

CAdE, T. J., P. Koskimies, AND Ó. K. NiElsen. 1998. Falco rusticolus Gyrfalcon. BWP Update 2(1):1-25.

Dement'ev, G. P., AND N. A. Gladkov. 1951. Birds of the Soviet Union 1:127-136. Sovetskaya Nauka. Moskva, Russia (English translation: Israel Program for Scientific Translations, Jerusalem).

EKENSTEDT, J. 2006a. Inventering av jaktfalk i Norrbottens Iän 1996-2005. [Monitoring Gyrfalcon in Norrbotten County 1996-2005, in Swedish.] Länsstyrelsen i Norrbottens län, Rapportserie nr 5/2006:129. Luleá, Sweden.

Ekenstedt, J. 2006b. Sex-ratio and genetic structure of the Gyrfalcon (Falco rustico$l u s$ ) population in Norway and Sweden. Department of Animal Ecology, Swedish University of Agricultural Sciences, Umeå, Sweden.

FALKDALEN, U., L. DANIELSSON, AND J. EKENSTEDT. 2005. Jaktfalken i Sverige 20032004. [The Gyrfalcon in Sweden 2003-2004, in Swedish.] Fågelåret 2004, Vår Fågelvärld, Suppl. 44:43-47.
Frydenlund-Steen, O., AND B. SøRli. 2005. Reirovervåking av jaktfalk i Telemark i 2005. [Gyrfalcon nest site guarding in Telemark County 2005, in Norwegian.] Våre Rovdyr 19:92-95.

Furuseth, L. E., AND P. FuRUSETH. 2009. Jaktfalk i Buskerud. Rapport fra kartleggingsarbeid i 2009. [Gyrfalcon in Buskerud County. Report 2009, in Norwegian.] Naturvernforbundet i Buskerud. Darbu, Norway.

Hagen, Y. 1952. The Gyr-falcon (Falco rusticolus L.) in Dovre, Norway. Some breeding records and food studies. Skrifter utgitt av det Norske Videnskaps-Akademi i Oslo, I. Matematisk-Naturvitenskapelig Klasse 4:137. Oslo, Norway.

Helland, A. 1906. Finnmarkens Amt. Topografisk-statistisk beskrivelse. Anden del. [Finnmark County. Topographic-statistic description. vol 2, in Norwegian.] Aschehoug \& Co, Kristiania [Oslo], Norway.

Johnsen, T. 2004. Status of the Gyrfalcon in north of Norway. Pages 12-13 in Proceedings from the Gyrfalcon Workshop, 28 September 2004, Umeå, Sweden.

Koskimies, P. 1999. International Species Action Plan. Gyrfalcon Falco rusticolus. BirdLife International \& European Commission, Brussels, Belgium.

Koskimies, P. 2006. Research on conservation biology of the Gyrfalcon Falco rusticolus in Northern Fennoscandia: Present status and future prospects. Pages 56-69 in P. Koskimies and N. Lapshin (Eds.). Status of Raptor Populations in Eastern Fennoscandia. Kostomuksha, Karelia, Russia, November 8-10, 2005. Karelian Research Centre of the Russian Academy of Science and Finnish-Russian Working Group on Nature Conservation.

Mossop, D. H., AND R. D. HAYES. 1994. Long term trends in the breeding density and productivity of Gyrfalcon Falco rusticolus in the Yukon Territory, Canada. Pages 403-413 in B.-U. Meyburg and R. D. Chancellor (Eds). Raptor Conservation 
Today. World Working Group on Bird of Prey, Pica Press, London, UK.

Newton, A., AND J. Wolley. 1864. Ootheca Wolleyana: An Illustrated Catalogue of the Collection of Birds Eggs. Part I. Accipitres. John van Voorst, Paternoster Row, London, UK.

Newton, I. 1979. Population Ecology of Raptors. T. \& A. D. Poyser, London, UK.

NiELSEN, Ó. K. 1986. Population ecology of the gyrfalcon in Iceland with comparative notes on the Merlin and the Raven. Ph.D. dissertation. Cornell University, Ithaca, New York, USA.

NiELSEN, Ó. K. 1999. Gyrfalcon predation on ptarmigan: Numerical and functional responses. Journal of Animal Ecology 68:1034-1050.

NiElSEN, Ó. K., AND T. J. CADE. 1990. Annual cycle of the Gyrfalcon in Iceland. National Geographic Research 6(1):41-62.

Nielsen, Ó. K., AND G. Pétursson. 1995. Population fluctutions of Gyrfalcon and Rockptarmigan: Analysis of export figures from Iceland. Wildlife Biology 1:65-71.

NRK SÁPMI. 2008. http://www.nrk.no/kanal/ nrk_sapmi/1.4934154

NySTRÖM, J., J. EKENSTEDT, J. ENGSTRÖM, AND A. ANGERbJÖRN. 2005. Gyr Falcons, ptarmigan and microtine rodents in Northern Sweden. Ibis 147(3):587-597.

OAKLEAF, R. 2003. Peregrine restoration from a state biologist's perspective: Wyoming. Pages 297-304 in T. J. Cade and W. Burnham (Eds.). Return of the Peregrine; A North American Saga of Tenacity and Teamwork. The Peregrine Fund, Boise, Idaho, USA.

OPHEIM, J. 2008. Forekomst av jaktfalk i Oppland fylke. [Abundance of Gyrfalcon in Oppland County, in Norwegian]. Våre Rovdyr 2:48-53.

ØStlyngen A., K. Johansen, AND P. Halvorsen. 2011. Artificial nests-A remedial action in maintaining viable Gyrfalcon populations? In R. T. Watson, T. J. Cade, M. Fuller, G. Hunt, and E. Potapov (Eds.). Gyrfalcons and Ptarmigan in a
Changing World. The Peregrine Fund, Boise, Idaho, USA. http://dx.doi.org/ 10.4080/gpcw.2011.0314Platt, J. B. 1976. Gyrfalcon nest site selection and winter activity in the western Canadian Arctic. Canadian Field-Naturalist 90:338-345.

Platt, J. B. 1989. Gyrfalcon courtship and early breeding behavior on the Yukon North Slope. Sociobiology 15:43-69.

Poole, K. G. 1988. A replacement clutch in wild Gyrfalcons, Falco rusticolus, in the Northwest Territories. Canadian Field Naturalist 102(1):62-64.

PoOle, K. G., AND R. G. BRoMLEy. 1988. Interrelationships within a raptor guild in the central Canadian Arctic. Canadian Journal of Zoology 66:2275-2282.

Potapov, E., ANd R. SAle. 2005. The Gyrfalcon. T. \& A. D. Poyser, London, UK.

Ratcliffe, D. 1993. The Peregrine Falcon, $2^{\text {nd }}$ ed. T. \& A. D. Poyser, London, UK.

Shank, C. C., AND K. G. Poole. 1994. Status of Gyrfalcon Falco rusticolus populations in the Northwest Territories, Canada. In B.U. Meyburg and R. D. Chancellor (Eds.). Raptor Conservation Today. World Working Group on Bird of Prey, Pica Press, London, UK.

SJÖLANDER, D. 1946. Zoologiska Lapplandsminnen [Zoological memories from Lapland, in Swedish]. Sveriges Natur's årsbok, Göteborg 37:95-107.

STATISTICS NORWAY. 2010a. http://statbank. ssb.no/statistikkbanken/Default_FR.asp? PXSid $=0 \& n v l=$ true $\&$ PLanguage $=0 \&$ tilside =selecttable/hovedtabellHjem.asp\& KortnavnWeb=srjakt

STATISTICS NORWAY. 2010b. http://statbank. ssb.no/statistikkbanken/Default_FR.asp?

PXSid $=0 \& n v l=$ true $\&$ PLanguage $=0 \&$ tilside =selecttable/hovedtabellHjem.asp\&

KortnavnWeb=bilreg

STATISTICS NORWAY. 2011. http://www.ssb.no/ aarbok/tab/tab-057.html

Steen, A., And O. Aarseth. 1988. Kautokeinoslekter. [Family book of Kautokeino, in Norwegian.] Norsk Folkemuseum, Oslo, Norway. 
Swem, T., C. McIntyre, R. J. Ritchie, P. J. Bente, AND D. G. Roseneau. 1994. Distribution, abundance, and notes on the breeding biology of Gyrfalcons Falco rusticolus in Alaska. In B.-U. Meyburg and R. D. Chancellor (Eds.). Raptor Conservation Today. World Working Group on Bird of Prey, Pica Press, London, UK.

The Directorate of Reindeer Husbandry. 2010. http://www.reindrift.no/?objid=305\& subid $=0 \&$ selected_tab $=2$

Tromholt, S. 1885. Under the Rays of the Aurora Borealis: In the Land of the Lapps and Kvæns. London, UK.

TøMmeraAs, P. J. 1993. The status of Gyrfalcon Falco rusticolus research in northern Fennoscandia 1992. Fauna Norvegica, Series C, Cinclus 16:75-82.

TøMmeRAAs, P. J. 1994. Jaktfalken, ripjägare på vikande front. [Gyrfalcon, Ptarmigan Hunter in Retreat, in Swedish.] Vår Fågelvärld 6:20-23.

TøMmERAAs, P. J. 1998. Jaktfalk Falco rusticolus på Nordkalotten. [Gyrfalcon in the North Calotte Region, in Norwegian]. Nordkalottrådets rapportserie 49:29-45. (English summary pages 6-7). Vads $\varnothing$, Norway.

TøMmeraAs, P. J. 2002. Har kongeørnen på Finnmarksvidda hatt en eksplosiv bestandsvekst de siste årene som kan forklare de enorme rovdyrskadeutbetalingene? [Has the Golden Eagle population in Finnmarksvidda had an explosive growth that can explain the enormous predator-killedkettle payouts, in Norwegian.] Våre Rovdyr 3-4:68-77.

TøMMERAAs, P. J. 2004. Jaktfalk på Nordkalotten. [Gyrfalcon in the North Calotte Region, in Norwegian.] Våre Rovdyr 2:3647.

TøMmervik, H., B. Johansen, I. TOMBre, D. TANNHEISER, K. A. HøgdA, E. GAARE, AND F. E. Wielgolaski. 2004. Vegetation changes in the Nordic Mountain Birch Forest: The Influence of grazing and climate change. Arctic, Antarctic, and Alpine Research 36:323-332.

Watson, J. 1997. The Golden Eagle. T. \& A. D. Poyser, London, UK.

WEIR, D. 1982. Cliff nesting raptors of the Kisaralik River, western Alaska. Pages 138-152 in Raptor Management and Biology in Alaska and Western Canada. US Fish \& Wildlife Service, Anchorage, Alaska, USA.

White, C. M., And T. J. CADE. 1971. Cliffnesting raptors and ravens along the Colville River in arctic Alaska. Living Bird 10:107-150. 